\title{
Corporate Social Responsibility (CSR) from Organizational Performance Perspective: Analysys of Pharmaceuticals Industries of Malakand Division
}

\author{
Alam Zeb ${ }^{1 *}$ \\ Muhammad Khalil Ur Rahman ${ }^{2}$ \\ Shabir Ahmad ${ }^{3}$
}

\begin{abstract}
This paper aims to explore corporate social responsibility from organizational performance perspective. This research was conducted on the pharmaceutical industries of Malakand division and by structured questionnaire data was collected from customer. 50 customers sample size was selected using convenience sampling techniques. Out of whom 40 questionnaires were received having response rate of $80 \%$ and are used for data analysis. Descriptive statistics, correlation analysis and regression analysis were used for analysis. Results of the research demonstrate that the associationamongcorporate social responsibility and organizational performance is positivein the pharmaceutical industries of Malakand division Pakistan.
\end{abstract}

Keywords: CSR, organizational performance, Industries.

1. Assistant Professor, Department of Commerce and Management Sciences,University of Malakand, email:alamzabmbams@gmail.com.

2. PhD-Scholer, Department of Commerce and Management Science, University of Malakand

3. Assistant Professor, Department of Commerce and Management Studies, University of Malakand. 
IBT Journal of Business Studies Volume 15(1), 2019

\section{INTRODUCTION}

Corporate social responsibility is promise of a firm for working in economically, publicly and globally supportable way that is clear and progressively satisfy to its stakeholder like investor, local communities, customer, employees business partners and society. Moreover, Manne and Wallich, (1972) stated that in a comprehensive meaning CSR is a responsibility taken action in which an organization have some degree of free agent to a situation that upcoming social objectives are forced on an organization by rules and law, and the organization workout no accountability when it implements them. Additionally they suggested three basic element of the CSR exercise and appear to be involved in the exercise of corporate responsibility. These three elements are setting of objectives; decision to where follow specified objectives, and lastly, the financing of these objectives. Among these studies another researcher stated that corporate social responsibility shows organization thoughts and answer to questions beyond the technical, economical and lawful wants of the organization (Davis, 1973).

Backman (1975), define CSR in the form of social indicators, social audit and social accounting and stated that these activities fulfill several aspects of social performance. Scholar furthermore, stated that social responsibility shows motives or objectives to which a business given weight. He also identified several example of CSR reduction in pollution, employment in minority groups, developed medicinal care, developed manufacturing well being and protection and employment of minority groups. Furthermore, CSR describes that a business should be answerable for its action which effect people, environment and their communities (Lawrence \& Weber, 2002). It joins with other disciplines likebusinessnationality, responsibility of an environment, environmental accountability and sustainable trade (Moon, 2004).

In the previous time CSR has developed much popular. Now a days a huge quantity of corporations' problem reports on CSR because of the increasing acceptance of CSR in modern centuries. Several firms containing pharmaceutical business are gradually looking formethods to lecture their societal and conservational powers (Nussbaum, 2009). Additionally, CSR is business'sreply to increasing community related regarding social, financial, and environmental influence of worldwide businesses. The organization overall performance is essentially depend on the properly business activities which belongs to social and environmental benefits which help in an organization sustainability and goodwill.

The world facing many socioeconomic problems like other industries pharmaceuticals industries also take a big part on corporate social responsibility. Similarly, pharmaceutical businessis an important business in the world issince it improves health related treatments (Nussbaum, 2009). Due to insulin growth in the 1920s, antibiotics introduction in 1940s and the polio vaccine development in the 1950s (Folland, et al, 2007) and several more medicines and injections to reserve wellbeing, and the medical product work like leader in the contest of CSR and also play big role in the field of universal fitness (Bale, 2003).

According to Environics (1999), research of the International Millennium Poll performed on CSR several countries now worldwide feel that an organization should not only focus on profit, offering jobs and following the laws but also to provide ethical standards and to contribute social initiatives. Similarly, several firms now days implementing mechanisms of CSR due to people managing and these firm feels that they have moral obligation to provide back to the culture in adding to successively a money-makingcorporation.

Page $\mid 76$ 
The goal of this research is to describe CSR instruments engaged in the direction of the emerging world from the standpoint of bioscience corporations themselves. CSR is different in the pharmaceutical industry from other industries CSR for the reason that the keyproduct, drug, is important for the humanity of well-being. According to Moon (2004), several individual can't manage to pay for luxurious cars or houses, a detail of slight importance. But since drugs are not just ordinary commodities as they are associated with life and death and between being sick and well, CSR in this perspective is determined quite differently as compared to other companies. Within this context the present study was conducted with the specific objective to observe the CSR on pharmaceutical industry in order to determine as to how corporate social responsibility that is education, health and donation affects Organization performance in terms of customer's satisfaction, competitiveness, sale growth andnew productin the field of pharmaceutical industries at Malakand division.

\section{LITERATURE REVIEW}

Ioannou and Serafeim (2014), explored the impact of CSR assessments on trade side investigation valuations of firm's upcoming commercial performance. They stated that an analyst when find CSR as agency cost, so they yieldnegative approvals for companies with big CSR assessments. They also found experienced analyst and higher status brokerage are among the key agents who shifted the relationship between CSR evaluations and investment approval cheerfulness. Malik and Nadeem (2014), explored social responsibility effect on the financial performance of banks in Pakistan. They stated that instead of significant connection between profitability and CSR practices, there is lack of CSR in Pakistan. They also found that the institution which have implemented CSR in their actionsthe long term periods they have more earning and more profit.

Shruti (2014), investigated CSR disclosure effect on the financial performance of firms in UK in three sectors including gas, petroleum industry of mining and pharmaceuticals. Her outcomes presented no important correlation among CSR disclosure and the financial performance. Abogun et al. (2013), they stated that CSR has attained high level of discourse between practitioners and scholar's in Nigeria. They also found the positive relationship between CSR expenditure and firm value. Mehar and Rahat (2007), show significance association of corporate social responsibility and firm financial performance.

Berete (2012), observe that pharmaceutical industries are increase their interest in CSR and also stated that factor like pressure, stakeholders, the economic health; the threats and the market place attractiveness are influencing the CSR of pharmaceutical industries. Mwangiand Jerotich (2013), presented that there was an important positive connection between corporate social responsibility practice and financial performance. They also show that the association between performance and manufacturing effectiveness is significant. Malik et al. (2015), stated that organizational culture are more important for the CSR activities and organizational performance they also stated the correlation between CSR activities and organizational performance and also CSR relation with employee performance in banking sector of Pakistan.

Shimada and Uryuhara (2010), investigated the pharmaceutical industries impact with CSR activities on the decisions of doctors regarding prescriptions medicines they show that due to CSR activities pharmaceuticals industries strengthen their position and status. Murtraza et al. (2014), concluded that CSR and corporate financial performance have positive correlation they also stated that if the firm increases their social activities it can improve image in the customers' mind and therefore organization may get huge advantages. Kiran et al. (2015), suggested that CSR is basically concern 
IBT Journal of Business Studies Volume 15(1), 2019

with society to share profit with it. They also concluded the positive association among CSR and net profit and negative relations between net profit and net profit margin. Salem and Carolina (2014), showed the connection between CSR and society they also discussed about CSR that pharmaceutical companies show CSR activities that can help reduce company's redundancies. Cornett et al. (2014), explored that the large organization seems to be rewarded that show high CSR activities.

The number of different CSR's definitions is huge. Perhaps the most compelling and comprehensive research by Dahlsrud (2008), analyzed the most commonly used CSR's definitions. For instance definition by Jones (1980), suggest that CSR is a concept that organization have duty to essential people in culture other than stockholders and outside that arranged by the contract of union showing that apole may go outside simple ownership. Marrewijk (2003), referred CSR to "corporation actions - controlled by definition - representing the attachment of societal and conservational worries in commercial processes and in connections with participants." Dahlsrud (2008), divided CSR's actions and explained into five dimensions summarized in a table below.

The five dimensions of CSR Dimensions

If it refers to the definition is coded to the dimension Example phrases

- Environmental dimension: Natural environment 'environmental stewardship' 'a cleaner environment' 'environmental concerns in business operations'

- Social dimension: Association among business and society 'contribute to a better society' 'integrate social concerns into their business operations' 'consider the full scope of their impact on communities'

- Economic dimension: Socio-economic or financial aspects, countingtelling CSR in relationships of a business operation 'contribute to economic development' 'preserving the profitability' 'business operations'

- Stakeholder dimension: Stakeholders or stakeholder groups 'interactions with their stakeholders' 'how organizations interact with their employees, suppliers, customers and communities' 'treating the stakeholders of the firm'

- Voluntariness dimension: Actions not approved by law 'based on ethical values' 'voluntary 'beyond legal obligations'

Hearst Newspapers published an article by M. Scilly from Demand Media named Five Dimensions of Corporate Social Responsibility (cited 2014-11-05), which describes them as follows:

- The environmental aspect of CSR denotes to organization's influence on the environment. The goal is to engage in business practices that benefit the environment.

- The social dimension of CSR involves the connectionamong organization and society. When talkingto the social dimension, a firm goal has to use its trade for the benefit of society.

- The economic dimension describes the effect that CSR has on organization's finances. It is significant to identify the economic impression that these actions have and to equilibrium being a responsible organization with production of revenue.

- The stakeholders are all of the people affected by organization's actions like suppliers, employees and the public members. There is a need to consider how organization's decisions make effect on these people.

- The voluntariness dimension is limited by activities that organization no needs to do it. These activities are built in what organization believes is the correct thing to do. They may be based in organization's specific ethical values. 
Kanwal et al. (2013), showed the concept of CSR in Pakistan and examined the optimistic correlation among CSR and financial performance of firm. Babalola and Abiodun (2012), they examined the connotation among corporate social responsibility and firms' effectiveness they also stated that on obeying CSR laws and regulations the firm will get more attention in Nigeria.

Carlsson and Akerstom (2008), studied on about company's engagement with CSR activities. They observed that some companies show beneficial relation while some show negative effect on company. Awan and Akhtar (2014), consider CSR as powerful tools for greater benefits for organization. They study on how fertilizer and cement industry of Pakistan engage with CSR. They concluded that firm must shares profit to society in the form of CSR activities.

Mackie et al. (2006), suggested that CSR policies expected at lecturing universal fitness issues is a plan bioscience businesses can practice to give rear to mortality. Volodina et al. (2009), stated the CSR practices toward pharmacy students including their concept and knowledge in Germany and Russia. They recognized that students believed be a part of CSR programs for the pharmaceutical companies. Kaufmann and Olaru (2012), research concluded that stakeholder concept is the conceivable way to extent CSR influence on business performance.

Hence from literature the following conceptual framework of corporate social responsibility and organizational performance has been developed.

Conceptual model

\begin{tabular}{|l|l|l|}
\hline $\begin{array}{l}\text { Corporate social } \\
\text { responsibility }\end{array}$ & Organizational performance \\
\cline { 2 - 3 }
\end{tabular}

\section{RESEARCH METHODOLOGY}

This research proposes the influence of Corporate Social Responsibility on organization performance in Malakand division. The data was collected from different Pharmaceuticals industries in Malakand division. Relational survey design was used to find out the association between CSR and firm performance. Convenience sampling method was selected in this research because of large population and geographical dispersion it was not possible to study all the pharmaceuticals companies' hence representative sample have been selected and through questionnaire the primary data was collected. After collection of Data it was analyzed through SPSS using descriptive statistics, regression analysis and correlation analysis.

\section{RESULTS}

The table 1 shows the number of items of corporate social responsibility and organizational performance. The number of items of corporate social responsibility is 14 while organizational performance contains on 6 numbers of items and 20 are the total number of items. According to thebelow table the cronbach alpha for the corporate social responsibility is 0.75 and for organizational performance is 0.71 , which shows that high level of consistency present in the variable. Hence the reliability statistics indicate that cronbach alpha is approximately 0.72 for all variables, which also indicates that high consistency level present in the dependent and independent variable. The question consist in each variables indicated by "N of items". For each variable cronbach alpha is given in the below table. 
IBT Journal of Business Studies Volume 15(1), 2019

Table 1.

Reliability statistics

\begin{tabular}{|l|l|l|}
\hline Cronbach's & Alpha & N of items \\
\hline Corporate social responsibility & 0.75 & 14 \\
\hline Organizational performance & 0.71 & 6 \\
\hline Overall reliability & 0.72 & 20 \\
\hline
\end{tabular}

The table 2 as given below shows descriptive statistics of the respondents. In this table the mean of gender is 0.52 while standard deviation is 0.50 . Similarly the respondent's qualification mean is 1.7 while standard deviation is 0.60 . In addition the mean of corporate social responsibility is 2.7 while standard deviation is 0.60 . Moreover, organizational performance mean is 3.9 while standard deviation is 0.50 . The total numbers of respondents are 40 .

Table 2.

Descriptive statistics

\begin{tabular}{|l|l|l|l|}
\hline & Mean & Std. Deviation & $\mathrm{N}$ \\
\hline Gender & .5250 & .50574 & 40 \\
\hline Qualification & 1.7 & 0.60 & 40 \\
\hline Corporate social responsibility & 2.7 & .62 & 40 \\
\hline Organizational performance & 3.9 & 0.54 & 40 \\
\hline
\end{tabular}

\section{Regression Analysis}

The below table $3 \mathrm{R}$ describes strength of the variables relationship. The value of $\mathrm{R}=0.779$ shows that there is $77.9 \%$ connotation among corporate social responsibility and organizational performance. The extent of variance in the dependant variable due to variations in independent variable is shows byAdjusted R square. The value of Adjusted R square is 0.606 shows that corporate social responsibility explains 60.6 variations in explaining organizational performance.

Table 3.

Model Summary

\begin{tabular}{|l|l|l|l|l|}
\hline Mode 1 & $\mathrm{R}$ & R Square & $\begin{array}{l}\text { Adjusted R } \\
\text { Square }\end{array}$ & $\begin{array}{l}\text { Std. Error of the } \\
\text { Estimate }\end{array}$ \\
\hline 1 & $.779 \mathrm{a}$ & .606 & .535 & .57211 \\
\hline
\end{tabular}

a. Predictors: (Constant), ages, MS Gender, Qualification, corporate social responsibility, organizational performance.

In the given table 4 the statistical significance of the model $(\mathrm{p}<.05)$ show by thevalue of $\mathrm{F}$. The $\mathrm{F}$ value is $8.464, p=.000(p<.05)$ sows the model is statistically significant. 
Table 4.

ANOVAb

\begin{tabular}{|l|l|l|l|l|l|}
\hline Model & Sum of Squares & Df & Mean Square & F & Sig. \\
\hline Regression & 16.622 & 6 & 2.770 & 8.464 & $.000 \mathrm{~b}$ \\
\hline Residual & 10.801 & 33 & .327 & & \\
\hline Total & 27.423 & 39 & & & \\
\hline
\end{tabular}

a. Predictors: (Constant), CSR

b. Dependent Variable: organizational performance.

The below table 5 shows the effect of individual independent variables on dependent variable. Whereas, the variables of age, gender, marital state and qualification are insignificant. Only the variables of corporate social responsibility are significant, which means that they have a role in determining the organizational performance.

Table 5.

Coefficientsa

\begin{tabular}{|l|l|l|l|l|l|l|}
\hline Model & $\begin{array}{l}\text { Unstandardized } \\
\text { Coefficients }\end{array}$ & $\begin{array}{l}\text { Standardized } \\
\text { Coefficients }\end{array}$ & T & Sig. & & \\
\hline & B & Std. Error & Beta & & & \\
\hline & Constant) & -.918 & .743 & & -1.236 & .225 \\
\hline & Csr & .371 & .167 & .276 & 2.218 & .034 \\
\hline & $\begin{array}{l}\text { Organizational } \\
\text { performance }\end{array}$ & .927 & .190 & .599 & 4.872 & .000 \\
\hline & Qualification & .111 & .158 & .080 & .698 & .490 \\
\hline & MS & .059 & .262 & .032 & .224 & .824 \\
\hline & Gender & .169 & .246 & .102 & .688 & .496 \\
\hline & Age & -.161 & .178 & -.114 & -.907 & .371 \\
\hline & $\begin{array}{l}\text { Dependent Variable: } \\
\text { organizational } \\
\text { performance }\end{array}$ & & & & & \\
\hline
\end{tabular}

\section{DISCUSSIONS}

The purpose of suchpaper to determine corporate social responsibility from organizational performance perspective among pharmaceuticals industries of Malakand division. On the basis of the above results it is found that there is significant and positive correlation between corporate social responsibilities (CSR) on organizational performance among pharmaceuticals industries of Malakand division. The results proved the hypotheses that there are significant relationship between corporate social obligation and organizational performance in long run while there is no significant relationship between corporate social responsibility and organizational performance in long run 
which is directly consistent with the results of Kanwal et al. (2013), Shruti (2014), Murtraza et al. (2014), and Awan and Akhtar (2014). Corporate social responsibility has positive relationship with organizational performance among pharmaceuticals industries of Malakand division. This result is similar with Kanwal et al. (2013), studies who describes that corporate social responsibility has significant relationship with organizational performance. Moreover, Shruti (2014), studies also similar with this research that corporate social responsibility has significant relationship with organizational performance. Furthermore, Murtraza et al. (2014), studies also relates with this study that corporate social responsibility has significant relationship with organizational performance. In addition, Awan and Akhtar (2014), result also relates with this research that corporate social responsibility has significant relationship with organizational performance.

\section{CONCLUSION}

This part of the study concludes the overall study. The objective of this study is to explore the impact of corporate social responsibility on organizational performance. As we know that many of the staff receives different amounts of education and health facilities. But the central part of the duties and responsibilities of the same job families are the same. The results of the study show that there is a direct and significant relationship between corporate social responsibility and organizational performance. There is also a considerable, more significant and affirmative relationship between corporate social responsibility and organizational performance. A considerable number of respondents were satisfied with the sum total of rewards while performing their job. But there were several of the respondents who responded negatively.On the basis of the findings of the research it can be recommended that CSR is the most important strategic approach that can be adopted by the pharmaceutical industry as it helps to build brand image. The managers need to focus more on building relations with the stakeholders and reflecting the needs and wants of the stakeholders particularly and the society in generally in the operations, practice and marketing of the organizations to achieve competitive advantage.

\section{REFERENCES}

Awan, A. G., \& Akhtar, N. (2014). The Impact of Corporate Social Responsibility (CSR) on Profitability of Firms: A Case Study of Fertilizer \& Cement Industry in Southern Punjab, Pakistan. International Journal of Development and Economic Sustainability, 2 (4), 70-79.

Babalola, Y. A. (2012). The impact of corporate social responsibility on firms' profitability in Nigeria. European Journal of Economics, Finance and administrative sciences, 45(1), 39-50.

Bereta, G., Kiser, P. D., Golczak, M., Sun, W., Heon, E., Saperstein, D. A., \& Palczewski, K. (2008). Impact of retinal disease-associated RPE65 mutations on retinoid isomerization. Biochemistry, 47(37), 9856-9865.

Carroll, A. B. (1979). A three-dimensional conceptual model of corporate performance. Academy of management review, 4(4), 497-505.

Carroll, A. B. (1999). Corporate social responsibility: Evolution of a definitional construct. Business \& society, 38(3), 268-295.

Carlsson, J., \& Åkerstöm, R. (2008). Corporate Social Responsibility: a case study of Öhrlings PricewaterhouseCoopers.

Cornett, M. M., Erhemjamts, O., \& Tehranian, H. (2014). Corporate social responsibility and its impact on financial performance: Investigation of US commercial banks. Unpublished manuscript.

Dahlsrud, A. (2008). How corporate social responsibility is defined: an analysis of 37 definitions. 
Corporate social responsibility and environmental management, 15(1), 1-13.

Davis, K. (1973). The case for and against business assumption of social responsibilities. Academy of Management journal, 16(2), 312-322.

Ioannou, I., \& Serafeim, G. (2015). The impact of corporate social responsibility on investment recommendations: Analysts' perceptions and shifting institutional logics. Strategic Management Journal, 36(7), 1053-1081.

Kaufmann, M., \& Olaru, M. (2012, March). The impact of corporate social responsibility on business performance-can it be measured, and if so, how. In The Berlin International Economics Congress (Vol. 1, pp. 1-16).

Kiran, S., Kakakhel, S., \& Shaheen, F. (2015). Corporate social responsibility and firm profitability: A case of oil and gas sector of Pakistan. City University Research Journal, 5(1), 110-119.

Lea, R. (2002). Corporate social responsibility: IOD member opinion survey. The Institute of Directors, UK, 10.

Lea, R. (2002). Corporate social responsibility: Institute of Directors (IoD) member opinion survey. IoD: London.

Mackie, J. E., Taylor, A. D., Daar, A. S., \& Singer, P. A. (2006). Corporate social responsibility strategies aimed at the developing world: perspectives from bioscience companies in the industrialised world. International journal of biotechnology, 8(1-2), 103-118.

Malik, M. S., \& Nadeem, M. (2014). Impact of corporate social responsibility on the financial performance of banks in Pakistan. International Letters of Social and Humanistic Sciences, 10(1), 9-19.

Mehar, A., \& Rahat, F. (2007). Impact of corporate social responsibility on firm's financial performance. South Asian Journal of Management Sciences (SAJMS), Iqra University, 1(1), $16-24$.

Mwangi, C. I., \& Jerotich, O. J. (2013). The relationship between corporate social responsibility practices and financial performance of firms in the manufacturing, construction and allied sector of the Nairobi Securities Exchange. International Journal of Business, Humanities and Technology, 3(2), 81-90.

Murtaza, I. A., Akhtar, N., Ijaz, A., \& Sadiqa, A. (2014). Impact of corporate social responsibility on firm financial performance: A case study of Pakistan. International Review of management and business research, 3(4), 1914.

Shimada, T., \& Uryuhara, Y. (2010). The Impact of a Pharmaceutical Company's CSR Activities on Doctors' Decisions about Prescription Drugs (No. 2010-11).

Singh, S. (2014). Impact of corporate social responsibility disclosure on the financial performance of firms in UK(Master's thesis, University of Twente).

Wherry, F. F., \& Schor, J. B. (Eds.). (2015). The SAGE encyclopedia of economics and society. SAGE Publications.

Vartiak, L. (2014). Activities of socially responsible companies operating in the Euroregion Beskydy. In Development of the Euroregion Beskydy VIII: international scientific conference.

Volodina, A., Sax, S., \& Anderson, S. (2009). Corporate social responsibility in countries with mature and emerging pharmaceutical sectors. Pharmacy Practice, 7(4), 228. 